Edubiotik: Jurnal Pendidikan, Biologi dan Terapan
ISSN 2528-679X (print), ISSN 2597-9833 (online)
Vol. 6, No. 01, February 2021, pp. 26-39
Available online at:
http://ejurnal.budiutomomalang.ac.id/index.php/edubiotik

Research Article

open 2 ACCESS

\title{
Validity of ESQ booklets about structure and function of animal tissue as biology learning supplement
}

\author{
Fadhilah Ikhtiarni, Ardi, Rahmawati Darussyamsu
}

Biology Education, Universitas Negeri Padang, Sumatera Barat, Indonesia

Email: fadilahikhtiarni12@gmail.com, ardibio@fmipa.unp.ac.id, rahmabio@fmipa.unp.ac.id

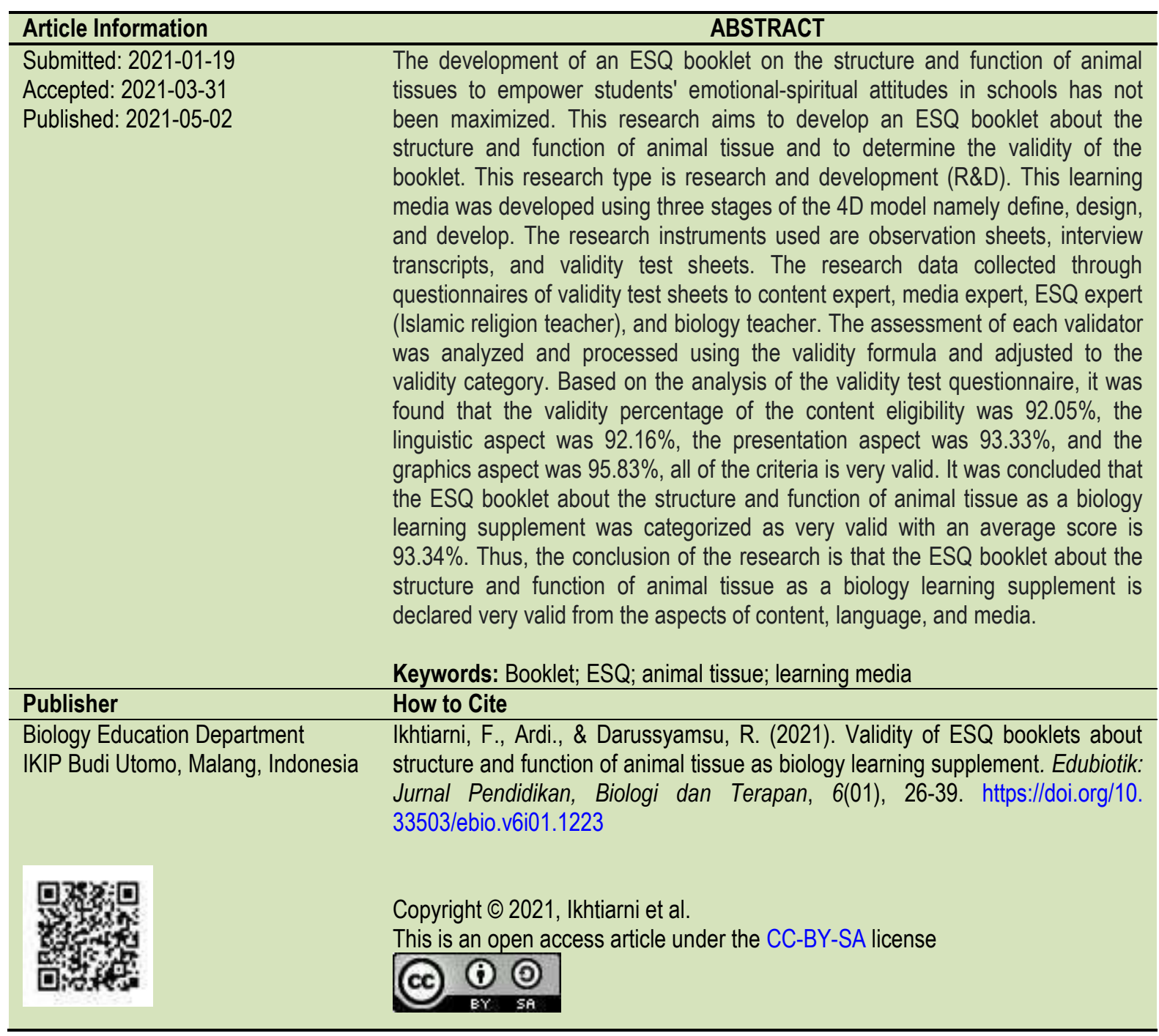

\section{INTRODUCTION}

The current curriculum in the Indonesian Education System is Curriculum 2013 (C-13). The aspects of assessment reviewed in $\mathrm{C}-13$ are spiritual, attitude, knowledge, and skills. Permendikbud No 35 (2018) describes that one of the characteristics of C-13 is to develop the balances of spiritual 
and social attitudes, knowledge, and skills of students and apply them in various situations in schools and communities. According to Riyana (2012), one of the efforts that can be carried out to balance these aspects is through learning media, the success of the learning process is supported by the learning media used. The functions of visual learning media according to Ismail (2020) are attention, affective, cognitive, and compensatory functions. The attention function serves to attract the attention and concentration of students, the affective functions provide students with emotions or attitudes towards images on the media, cognitive functions to accelerate students to understand information, and the compensatory function is to make it easier for students with weak abilities to remember information.

The use of visual learning media will help students understand pictorial content in lessons. Biology learning in High School requires appropriate learning media to help students understand biology content. According to Sepriadi et al. (2018), biology lessons require the ability to think critically, inductively, and dedicate students to solve problems regarding phenomena in living things at various levels of life. Therefore, learning media that are suitable for biology content are needed to make it easier for students to understand abstract material and cannot be observed directly. Based on observations for 30 students at SMAN 1 Pulau Punjung on 28 September 2020, it was revealed that students felt bored, unmotivated, did not like reading existing biology learning media, and had difficulty understanding the material in the learning media, as a result, in the learning process students became less active and students' daily tests are low.

Based on an interview with one of the biology teachers in SMAN 1 Pulau Punjung on 25 September 2020, it was revealed that the learning media used in biology learning are PowerPoint slides, animated videos, student worksheets, and modules containing learning materials prepared by the teacher. This learning media is always used in every biology material, so the teacher reveals that students seem bored and unmotivated in using existing learning media. Biology teachers stated that the lack of time and the lack of competence of teachers in developing interesting and varied learning materials was the cause of using the same learning media in every biology topic. Therefore, teachers need a new interesting learning media and able to increase student motivation and make it easier for students to understand biology content. According to Nurseto, (2011), current learning emphasizes process skills and active learning, demanding that the use of lecture methods be reduced and replaced by the use of various learning media. Various learning media can provide new learning experiences for students, besides that, it can increase students' motivation in reading learning materials. The biology teacher also stated that the allocation of time is not by the amount of Biology content causes students to need independent learning time out of the class, but students do not have independent learning media. Students need independent learning media in the form of supplements that are used side by side with the main learning media. The solution to the limited allocation of learning time in schools according to Warliah et al. (2018), is to use learning media that allow the learning process to be carried out anytime and anywhere and can be used independently for students as a learning supplement.

One of biology material that is difficult for students to understand in grade XI based on observation is the material on the structure and function of animal tissue because there are many pictures of animal tissue structures that are difficult to distinguish by students. The images presented in the existing learning media used by students do not have good quality pictures and seem unattractive and unclear and do not explain the structure of animal tissue well. The structure and function of animal tissue material is the most difficult material evidenced by the low test scores of 
students on animal tissue material compared to other materials in the first semester in class $\mathrm{XI}$. Students stated that they had difficulty understanding the material on existing learning media, and the existing learning media do not make students interested and motivated to read.

According to Maemunawati \& Alif (2020), the use of instructional media serves to raise students' interest and motivation, with the use of interesting learning media that will provide a sense of enthusiasm and a pleasant atmosphere for students in learning. Based on the problems experienced by students and biology teachers regarding the use of learning media, one of the learning media that can attract reading interest, motivate students, has high-quality images, attractive appearance, and suitable to be used as a learning material supplement that can be used independently by students is a booklet. According to Atiko (2019), The advantages of booklets for students are forming confidence in the notes provided by educators, promoting booklets to other students, so that students are curious and interested in reading booklets, arousing students interest in reading to completion, as well as with the pictures on the booklets, students easier to understand learning material. Based on interviews with teachers, booklets have never been used as biology learning media. According to Gilissen et al. (2020), teachers must be able to professionally develop learning materials innovatively and creatively.

Based on literacy studies, some biology materials have been developed in the form of a booklet and obtained valid values. Several booklets that have been developed are human motion system booklets, cell division booklets (Fitri, 2020), hereditary patterns booklets (Samhuliya, 2019), pteridophyta diversity booklets fitriasih et al. (2019), phylum echinodermata booklet (Indasari, 2016), immune system booklet Puspita et al. (2017), dragonfly species diversity booklet (Purnomo \& Rahayuningsih, 2020) and other booklets. Based on literacy studies, there have been various valid media developed regarding animal tissue materials. Several media developments are in the form of catalogs (Nurhidayah \& Haryunita, 2020), inquiry-based modules (Natsir, 2016), interactive multimedia (Kinanti, 2015), illustrated pocket books (Yulmi, 2018), Android-based m-learning (Arifuddin \& Bahri, 2019), LKPD based on Paikem Gembrot (Hasim, 2020), integrated worksheet (Kotimah \& Ambarwati, 2020) and other media. As far as the literacy study conducted by the author, there has not been any development of booklets on the structure and function of animal tissues, therefore this booklet has been developed as a complement to the collection of learning media for material on animal tissue structure and function.

Based on an interview with one of the Islamic religious teachers on 18 February 2021, it was revealed that there were still many students' emotional-spiritual attitudes that were not in accordance with the essence competencies in the C-13. According to Permendikbud No 37 (2018) the spiritual aspects expected in the first essence competencies of the 2013 curriculum is to live and practice of the religion they adhere to, the emotional aspects of students that are expected in the C-13, namely showing honest, disciplined, responsible, caring behavior (cooperation, tolerance, peace), polite, responsive, and pro-active as part of the solution to various problems in interacting effectively with the social and natural environment and placing oneself as a reflection of the nation in world relations. The obstacle experienced by religious teachers is the difficulty in increasing the emotional-spiritual value of students because many factors affect students.

Family environmental factors, friendship, daily viewing, and upbringing of the closest people affect the emotional-spiritual attitude of students. The Islamic religion teacher stated that he had tried to increase the emotional-spiritual value of students by holding religious extracurricular activities. Islamic religious teachers need support from other subjects teachers to increase the emotionalspiritual value of students by providing an ESQ nuanced on the learning materials used, this can be an 
effort to increase the emotional-spiritual value of students. According to Mirza et al. (2018), learning media with ESQ nuances can make it easier for students to learn and generate spiritual values that are expected to create valuable and meaningful learning. Learning media with emotional spiritual quotient (ESQ) values can be combined with biology content to generate gratitude for students for the power of God, balance the spiritual, affective, and cognitive abilities of students, and create valuable and meaningful lessons.

Based on previous research literacy studies, there are several valid biology learning media with $E S Q$ values. Some of the ESQ nuanced learning media that have been developed are ESQ nuanced modules on circulatory system material Putra et al. (2017) ESQ nuanced modules on evolutionary material Rahmadhani et al. (2019), interactive multimedia with ESQ nuances on system materials human circulation ESQ-nuanced Biology module on material coordination systems in humans and other ESQ nuanced media. Based on the literacy search by the author, there has been no research on the development of ESQ Booklet as a learning media. Biology teachers revealed that biology learning media used so far did not have ESQ nuances, so students had never had an ESQ value learning experience.

According to Herwati (2016) ESQ (Emotional Spiritual Quotient) consists of emotional intelligence, namely the ability to understand, manage, motivate self, and know the emotions of others, spiritual intelligence is the ability to manage the spiritual values of human life, emotional intelligence, spiritual, and intellectual are interconnected and lead to success. According to Fauziyati (2019), one way to increase intelligence is through literacy, education does not only rely on intellectual intelligence but also requires emotional and spiritual intelligence, is expected to provide student learning experiences and increase students' gratitude towards Allah SWT and have better emotional intelligence. Using ESQ learning materials is an effort to balance all of the essential competencies in C-13 that are spiritual, affective, cognitive, and skill values of students.

Based on the problems by students, biology teachers, and Islamic religion teachers obtained from observations and interviews, the author aims to develop and determine the validity of learning materials in the form of ESQ booklets on the structure and function of animal tissue. The absence of previous research on ESQ booklets on the structure and function of animal tissue as described above is also the reason for the author in developing an ESQ booklet. The ESQ nuanced booklet is expected to increase the spiritual and emotional value of students to provide a valuable and meaningful learning experience by generating gratitude to Allah SWT and being responsible for the health of the body. Students are expected to be motivated and have new learning experiences and prefer to read learning materials. This learning material supplement is expected to assist teachers in explaining the material on the structure and function of animal tissue with high-quality images.

\section{RESEARCH METHODS}

This research is development research that aims to produce a new product, namely an ESQ booklet about the structure and function of animal tissue as a biology learning supplement for grade XI science of high school students. The development model used is three stages of the 4D development model, namely define, design, and develop. The defined stage carried out the preliminary and final analysis, student analysis, concept analysis, task analysis, and analysis of learning purpose. The design stage includes media selection, format selection, and initial design. The development stage includes the validity test stage. The product developed will be validated by four validators consisting of two lecturers from the Department of Biology, Faculty of Mathematics and Natural Sciences as a 
content expert and media expert, one Islamic religion teacher as ESQ expert, and one biology teacher. The research instrument used was a product validity test questionnaire by the product validity grid.

The ESQ booklet about the structure and function of animal tissue was tested on the validator. The results of the validity test from the validator will be analyzed to see the validity of the designed product. Analysis of the results of the validity test was carried out in the following stages.

a. Provide an answer score with a modified Likert scale from (Purwanto, 2018) as follows.

$\begin{array}{ll}\text { STS (Strongly Disagree) } & \text { : Score } 1 \\ \text { TS (Disagree) } & \text { : Score } 2 \\ \text { S (Agree) } & \text { : Score } 3 \\ \text { SS (Strongly agree) } & \text { : Score } 4\end{array}$

b. The validity value of the product developed was determined by the modified content validity coefficient from the research from Rehusisma et al. (2017), with the following formula.

Explanation:

$$
V=\frac{T s r}{T m s} \times 100 \%
$$

$V=$ Validity

$T s r=$ Total Score Result

$T m s=$ Total Maximum Score

c. Provide a validity assessment according to the modified criteria of (Arikunto, 2010) as follows (see Table 1).

Table 1. Product Validity Criteria

\begin{tabular}{ccc}
\hline Validity Value Range (\%) & Criteria & Conclusion \\
\hline $81-100$ & Very Valid & Products can be used without revision \\
$61-80$ & Valid & Product requires minor revision before use \\
$41-60$ & Less Valid & Product requires multiple revisions before use \\
$\leq 40$ & Invalid & Products still need intensive consultation \\
\hline
\end{tabular}

\section{FINDINGS AND DISCUSSION}

The results of the study were obtained from four validators, namely content experts, media experts, ESQ experts, and biology teachers. The development model used is three stages of the 4D development model, namely define, design, and develop. The defined stage carried out the preliminary and final analysis, student analysis, task analysis, concept analysis, and analysis of learning purpose. The design stage includes media selection, format selection, and initial design. The development stage includes the validity test stage (Fransisca, 2017).

Define stage, includes preliminary and final analysis, student analysis, concept analysis, task analysis, and analysis of learning purpose. The preliminary and final analysis stage aims to determine the problems that occur at SMAN 1 Pulau Punjung during the Biology learning process. Based on interviews with Biology teachers at SMAN 1 Pulau Punjung, it was revealed that students were less motivated in the learning process because the learning media did not vary. Islamic religion teacher stated that students behavior during learning is also not following the affective spiritual indicators required in the $\mathrm{K}-13$.

The instructional media used by teachers in the form of LKPD, modules, Powerpoint slides, and animated videos do not have ESQ nuance. Based on the results of the student observation questionnaire analysis, it is known that $67 \%$ of students feel bored with the learning media used, $70 \%$ of students are not focused, unmotivated, and have difficulty understanding the material in the learning 
media. During the learning process, students often do not bring the learning materials that have been provided by the teacher because of forgetting, and the size is large and heavy. It is known from the results of interviews with teachers that booklets have never been used as teaching materials for biology, $100 \%$ of students have never used booklets as independent teaching materials. The complexity of the material with the time allocation provided for Biology learning according to the Biology teacher is not yet commensurate, where students need independent learning time to understand Biology content that is pictorial, and cyclical. Based on the results of interviews and student observation questionnaire analysis, the development of learning media with the nuances of ESQ was chosen as a Biology learning media to help students understand learning materials independently, increase motivation, and provide a new learning atmosphere for students.

Student analysis is obtained based on the analysis of student observations, it is known that most students learn visually. $87 \%$ of students stated that easier to understand the material if the learning materials used are colorful and interesting, students also find it easier to remember material that is pictorial and colored. $93 \%$ of students like learning materials that are given additional external information, and are given ESQ nuances. $73 \%$ of students liked learning materials that contained explanations for difficult terms, $100 \%$ of students liked learning materials that were equipped with concept maps. According to Harahap et al. (2020), the learning media criteria that students want for learning media still do not have existing learning media. Based on the student's analysis, one of the interesting media, which can be equipped with a concept map, the nuances of ESQ, new information, and explanations for difficult terms, as well as pictorial and colorful is a booklet. Therefore, the booklet was chosen as a media that fulfills the desires of students to increase student's motivation in learning.

Concept analysis aims to identify the main concepts in Biology learning materials. Concept analysis was obtained from the results of interviews with Biology teachers and student observation questionnaires regarding material that were difficult for students to understand, so it was necessary to develop booklets as a supplement to teaching materials. According to (Fakhrurrazi, 2018), the success of the learning process does not always depend on the educator but involves many factors including the activeness of students, the availability of learning facilities, safety, and classroom safety to create effective learning conditions. As many as $63.33 \%$ of students chose the structure and function of animal tissue material which was difficult for students to understand in class XI, this is in line with the interview with the biology teacher, this material is considered difficult because many animal tissue images are difficult to distinguish by students. Material structure and function of animal tissue includes epithelial tissue, connective tissue, nerve tissue, muscle tissue, and disorders of each tissue, the complexity of the material, and the cognitive level of analysis (C4), causing this material to become considered difficult by students. The average daily test for class XI students of SMAN 1 Pulau Punjung in 2019 the lowest was in the material structure and function of animal tissue, namely with an average of 70.50 , while the KKM set was 75 can be seen in Table 2. The average of less score than KKM of students in daily tests of animal tissue structure and function in 2019 was $67.15 \%$, while in 2020 as much as $68.08 \%$ can be seen in Table 3, more than half of the students did not complete daily tests on structure and function material animal tissue. Based on the data obtained, learning materials were developed in the form of ESQ nuanced booklets on animal tissue structure and function materials which are expected to be able to improve students understanding of animal tissue structure and function material. 
Table 2. Average Daily Test Class XI Semester 1 Year 2019

\begin{tabular}{|c|c|c|c|c|c|c|}
\hline \multirow{2}{*}{ KD } & \multirow{2}{*}{ Topics } & \multicolumn{4}{|c|}{ Natural Sciences Grade XI } & \multirow{2}{*}{ Average } \\
\hline & & 1 & 2 & 3 & 4 & \\
\hline 3.1 & Cell & 78 & 75 & 76 & 65 & 73,50 \\
\hline 3.2 & Transport of substances & 76 & 74 & 74 & 75 & 74,75 \\
\hline 3.3 & Plant tissue & 74 & 68 & 71 & 70 & 70,75 \\
\hline 3.4 & Animal tissue & 74 & 70 & 70 & 68 & 70,50 \\
\hline 3.5 & Motion system & 77 & 74 & 70 & 72 & 73,25 \\
\hline 3.6 & Circulatory system & 78 & 74 & 73 & 73 & 74,50 \\
\hline 3.7 & Digestive system & 71 & 73 & 74 & 70 & 72,00 \\
\hline
\end{tabular}

Table 3. Percentage of Less of KKM score in Animal Tissue Daily Test

\begin{tabular}{|c|c|c|c|c|c|}
\hline \multirow[b]{2}{*}{ Year } & \multirow{2}{*}{$\begin{array}{c}\text { Natural Sciences } \\
\text { Grade XI }\end{array}$} & \multirow{2}{*}{$\begin{array}{l}\text { The number of } \\
\text { students }\end{array}$} & \multicolumn{2}{|c|}{ Score } & \multirow{2}{*}{$\begin{array}{l}\text { Percentage of Less of } \\
\text { KKM score (\%) }\end{array}$} \\
\hline & & & $<K K M(<75)$ & $\geq 75$ & \\
\hline 2019 & 1 & 34 & 20 & 14 & 58,82 \\
\hline 2019 & 2 & 36 & 23 & 13 & 63,88 \\
\hline 2019 & 3 & 34 & 23 & 11 & 67,64 \\
\hline 2019 & 4 & 33 & 26 & 7 & 78,78 \\
\hline \multicolumn{2}{|r|}{ Count } & 137 & 92 & 45 & 67,15 \\
\hline 2020 & 1 & 31 & 18 & 13 & 58,06 \\
\hline 2020 & 2 & 32 & 21 & 11 & 65,62 \\
\hline 2020 & 3 & 31 & 25 & 6 & 80,64 \\
\hline \multicolumn{2}{|r|}{ Count } & 94 & 64 & 30 & 68,08 \\
\hline
\end{tabular}

Task analysis aims to detail the booklet material being developed. This analysis identifies and analyzes basic competencies and indicators of competency achievement by the essential competencies in the 2013 Curriculum. Essence competencies of material structure and function of animal tissue (see Table 4), basic competencies of material structure and function of animal tissue (see Table 5), and Indicators of competence achievement on material structure and function of animal tissue (see Table 6).

Table 4. Essence Competencies of Material Structure and Function of Animal Tissue

\begin{tabular}{c}
\hline Aspects \\
Spiritual \\
Affective \\
$\begin{array}{c}\text { 2. Demonstrate honest behavior, discipline, responsibility, care (mutual cooperation, } \\
\text { cooperation, tolerance, peace), courteous, responsive, and pro-active as part of the solution } \\
\text { to various problems in interacting effectively with the social and natural environment and } \\
\text { placing self as a reflection of the nation in world relations }\end{array}$ \\
3. Understand, apply, analyze factual, conceptual, procedural knowledge based on their \\
curiosity about science, technology, arts, culture and humanities with insight into humanity, \\
nationality, statehood and civilization related to the causes of phenomena and events, and \\
apply procedural knowledge to the field of study that devoted to the talents and interests of \\
solving problems
\end{tabular}

Table 5. Basic Competencies of Material Structure and Function of Animal Tissue

\begin{tabular}{ccc}
\hline Aspects & & KD \\
\hline Cognitive & 3.4 & To analyze the relationship between cell structure in animal tissues and organ functions in \\
Psychomotor & & animals
\end{tabular}


Table 6. Indicators of Competence Achievement on Material Structure and Function of Animal Tissue

\begin{tabular}{|c|c|}
\hline Aspects & IPK \\
\hline Cognitive & $\begin{array}{l}\text { 3.4.1 Identifying tissues in animals. } \\
\text { 3.4.2 Analyzing the relationship between the structure, location, function of the epithelium } \\
\text { based on the shape and number of cell layers. } \\
\text { 3.4.3 Linking the structure and location of various types of connective tissue and their functions. } \\
\text { 3.4.4 Linking the structure and location of various types of muscle tissue and their functions. } \\
\text { 3.4.5 Linking the structure of various types of nerve cells and their functions. }\end{array}$ \\
\hline Psychomotor & 4.4.1 Observing animal tissue preparations using a microscope \\
\hline
\end{tabular}

Analysis of learning purpose is used to analyze what learning purpose must be achieved by students in learning. In the material on the structure and function of animal tissue, the learning objectives that must be achieved by students are to analyze the relationship between cell structure in animal tissue and the function of organs in animals. Therefore, a booklet was developed that makes it easier for students to understand images that are abstract and cannot be observed directly with an attractive appearance to achieve predetermined learning objectives.

Design stage including media selection, format selection, and initial design. Media selection is based on the results of interviews with biology and Islamic religion teachers and observations with students. It is revealed that there is no available learning media that is interesting and ESQ nuanced on the structure and function of animal tissue material. $100 \%$ of students have never used learning media in the form of booklets. Teachers use media in the form of LKPD, modules, PowerPoint slides, and animated videos which are still not varied and make students feel bored and unmotivated by using existing learning media. The teacher stated that the lack of time and the lack of teacher competence in developing attractive teaching materials became obstacles in creating interesting teaching materials for students. Therefore, an ESQ nuanced booklet on the structure and function of animal tissue was developed as a supplement to Biology teaching materials for students in class XI IPA SMA. The format selection stage aims to choose an appropriate format for making booklets to create attractive booklets, while the format specified in the format of the type of font, the size of the font, and everything related to the format of the booklet. The initial design stage aims to design, create, and develop a content outline for the booklet.

The stages carried out at this stage are determining the application to be used, the type of paper, reference sources, high-resolution images, ESQ values, the estimated number of pages, cover design and content display, color, to produce a prototype booklet. At the initial design stage, the Microsoft Publisher 2010 application was used to compile the booklet, the Remini application to increase the image resolution in the booklet, the PicsArt application, and Paint to design the suitability of the image. The type of paper used is white manila paper with a size of A5 $148 \times 210 \mathrm{~mm}$. The estimated number of booklet pages is no more than 30 pages. The cover is designed by selecting the image of a tiger in a head arrangement of the skeleton, muscles, and full head tiger to symbolize that the animal's body is composed of various tissues. The content framework of the booklet that is designed is cover, introduction, learning competence, concept map, material, ESQ nuances, Bio info, glossary, and bibliography. The theme colors in the booklet are navy blue, gray, crème, and other colors that are adjusted to the appearance of the booklet. The types of writing used are Arial Narrow and Berlin sans FB with sizes adjusted to the appearance of the booklet. According to Pralisaputri et al. (2016) booklets as effective and efficient learning media that contain important information, are uniquely designed, clear, and easy to understand, so that booklets can be used as companion learning tools for learning activities in class or independently. 
The third stage is developed where validity tests. The product resulting from the design stage is revised according to suggestions by the validator. The content validator is responsible for checking content appropriateness, language, and presentation. The media validator is responsible for checking the graphics of the product. The ESQ validator is responsible for checking the appropriateness of the ESQ content, ESQ language, and ESQ presentation. The biology teacher validator is responsible for checking the appropriateness of the content, language, presentation, and graphics of the product. Validators for media experts and content experts from biology lecturers, FMIPA, UNP, namely Ganda Hijrah Selaras, M.Pd, and Sa'diatul Fuadiyah, M.Pd. The expert validator of ESQ from the Islamic religion teacher at SMAN 1 Pulau Punjung, Ahmad Husen, S.Ag., M.Pdl. The validator from a biology teacher is Desi Dahlan, M.Pd. At the validity stage, several revision stages were carried out to improve the booklet in terms of material and graphics. The improvements made are reevaluated until the product is declared worthy of being assessed for its validity aspect. The front cover of the booklet before and after revision (see Figure 1). Display of booklet mind map before and after revision (see Figure 2). Display of booklet material before and after revision (see Figure 3).

Analysis of the validity test questionnaire from content experts can be seen in Table 7 . The results of the validity of the media experts can be seen in Table 8. The results of the validity of the ESQ experts can be seen in Table 9. The results of the validity from biology teachers can be seen in Table 10. The results of the questionnaire analysis of validity test are obtained from the acquisition score on the validity test questionnaire with a Likert scale, then uses a formula to determine the validity value, and categorized according to the criteria described in the research method above. The summary of the validity tests of the four validators can be seen in Table 11.
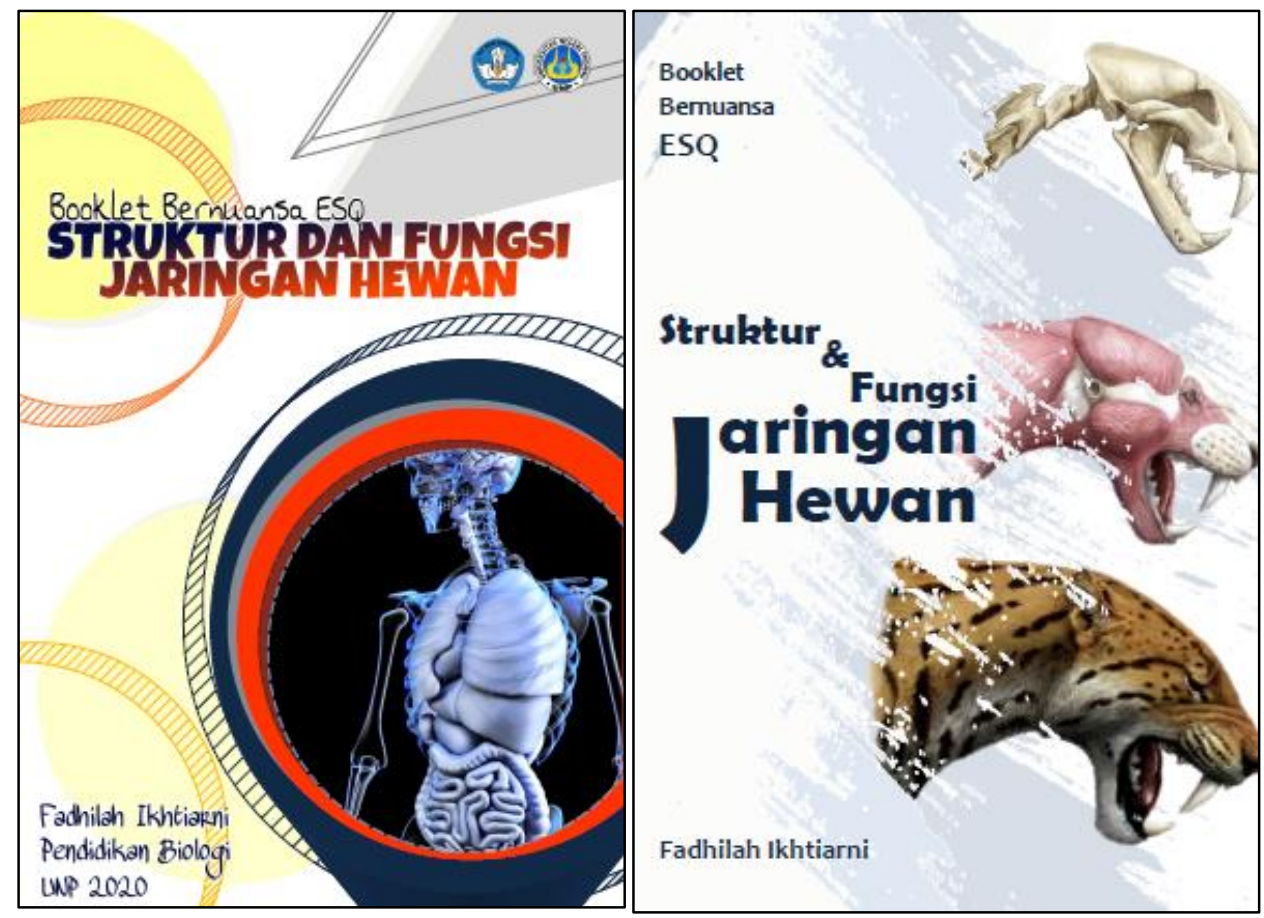

Figure 1. The Front Cover of the Booklet Before and After Revision 


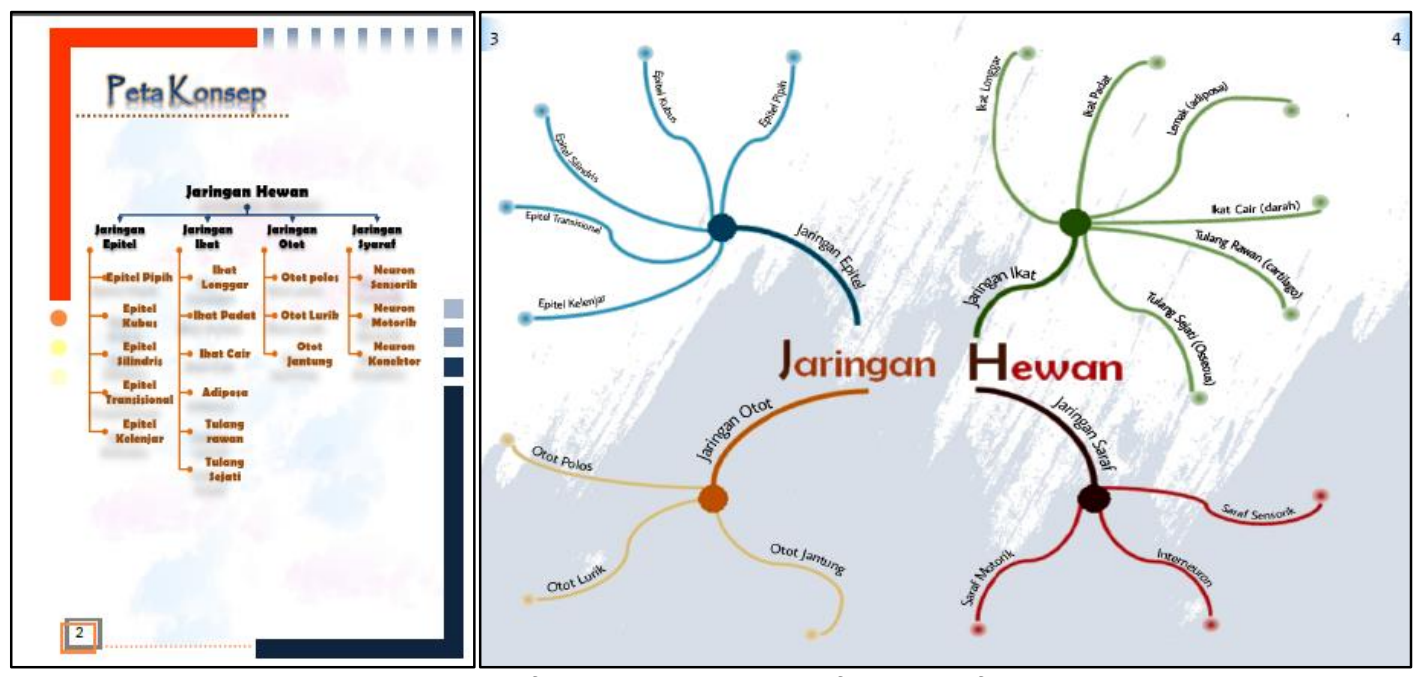

Figure 2. Display of Booklet Mind Map Before and After Revision

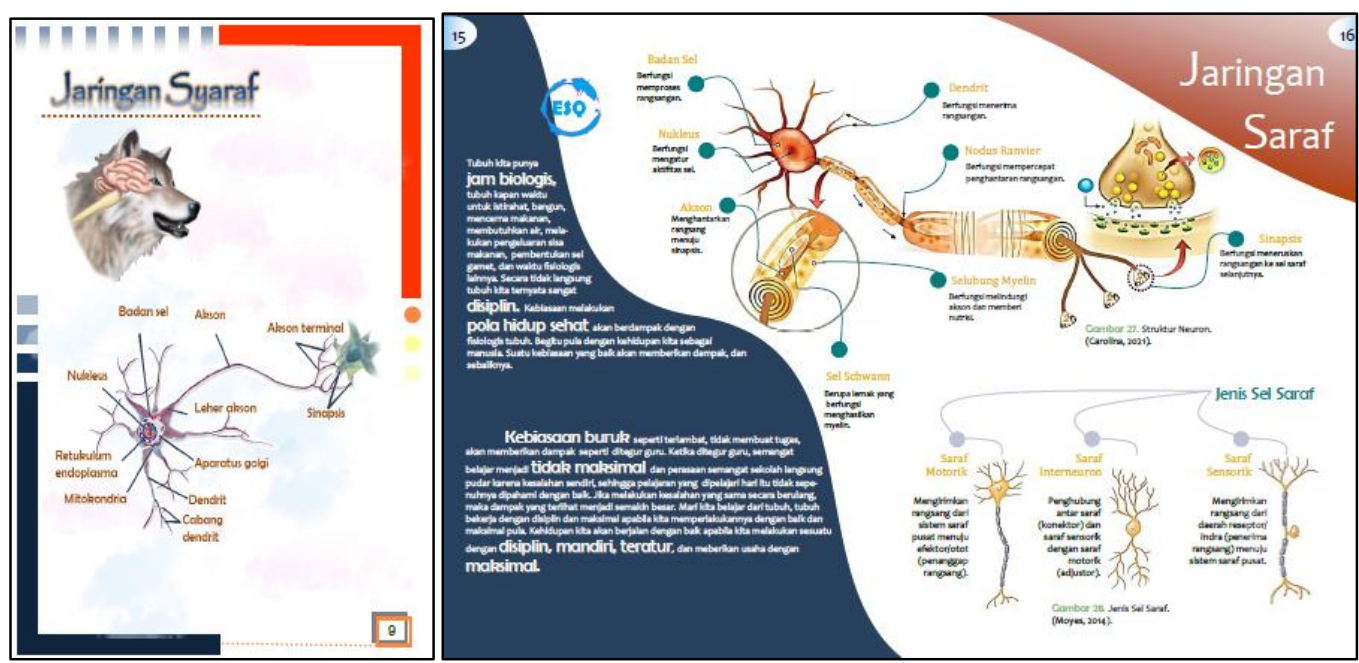

Figure 3. Display of Booklet Material Before and After Revision

Table 7. Content Validity Analysis from Content Experts

\begin{tabular}{ccccc}
\hline Aspects & Score Result & Maximum Score & Validity Score \% & Criteria \\
\hline Content eligibility & 32 & 27 & 84,38 & Very Valid \\
Language & 40 & 34 & 85,00 & Very Valid \\
Presentation & 20 & 19 & 95,00 & Very Valid \\
\hline
\end{tabular}

Table 8. Media Validity Analysis from Media Experts

\begin{tabular}{ccccc}
\hline Graphic Aspects & Score Result & Maximum Score & Validity Score $\%$ & Criteria \\
\hline Font & 12 & 12 & 100,00 & Very Valid \\
Colour & 8 & 8 & 100,00 & Very Valid \\
Layout & 11 & 12 & 91,67 & Very Valid \\
Pictures & 8 & 8 & 100,00 & Very Valid \\
Display Design & 37 & 40 & 92,50 & Very Valid \\
\hline
\end{tabular}

Table 9. ESQ Validity Analysis from ESQ Experts

\begin{tabular}{ccccc}
\hline Aspects & Score Result & Maximum Score & Validity Score $\%$ & Criteria \\
\hline Content eligibility & 27 & 28 & 96,43 & Very Valid \\
Language & 31 & 32 & 96,88 & Very Valid \\
Presentation & 18 & 20 & 90,00 & Very Valid \\
Graphics & 20 & 20 & 100,00 & Very Valid \\
\hline
\end{tabular}

Ikhtiarni et al. - Validity of ESQ booklets about structure and function of animal tissue as ... 
Table 10. Booklet Validity Analysis from Biology Teacher

\begin{tabular}{ccccc}
\hline Aspect & Score Result & Maximum Score & Validity Score \% & Criteria \\
\hline Content eligibility & 27 & 28 & 96,43 & Very Valid \\
Language & 29 & 32 & 90,63 & Very Valid \\
Presentation & 19 & 20 & 95,00 & Very Valid \\
Graphics & 19 & 20 & 95,00 & Very Valid \\
\hline
\end{tabular}

Table 11. Booklet Validity Analysis From Four Validators

\begin{tabular}{|c|c|c|c|c|c|c|c|c|}
\hline \multirow{2}{*}{ Variabel } & \multicolumn{4}{|c|}{ Validators } & \multirow{2}{*}{$\begin{array}{c}\text { Total Score } \\
\text { Result }\end{array}$} & \multirow{2}{*}{$\begin{array}{c}\text { Maximum } \\
\text { Score }\end{array}$} & \multirow{2}{*}{ Validity Score \% } & \multirow{2}{*}{ Criteria } \\
\hline & 1 & 2 & 3 & 4 & & & & \\
\hline Content eligibility & 27 & & 27 & 27 & 81 & 88 & 92,05 & Very Valid \\
\hline Language & 34 & & 31 & 29 & 94 & 102 & 92,16 & Very Valid \\
\hline Presentation & 19 & & 18 & 19 & 56 & 60 & 93,33 & Very Valid \\
\hline Graphics & & 76 & 20 & 19 & 115 & 120 & 95,83 & Very Valid \\
\hline \multicolumn{7}{|c|}{ Average } & 93,34 & Very Valid \\
\hline
\end{tabular}

Explanation:

Validator 1= Sa'diyatul Fuadiyah, M.Pd (content expert)

Validator 2= Ganda Hijrah Selaras, M.Pd (media expert)

Validator 3= Ahmad Husen, S.Ag., M.Pdl (ESQ expert)

Validator 4= Desi Dahlan, M.Pd (biology teacher)

Based on the analysis of the validation test questionnaire by the validator on the aspect of validation assessment, it was found that the ESQ booklet about the structure and function of animal tissue obtained a very valid value with an average of $93.34 \%$. Aspect indicators of the content eligibility, language, and presentation were obtained from assessments by a content expert, ESQ experts, and biology teachers. The graphic aspects were obtained from assessments by media experts, ESQ experts, and biology teachers. The validity value of the content eligibility aspect is $92.05 \%$ with very valid criteria, the language aspect is $92.16 \%$ with very valid criteria, the presentation aspect is $93.33 \%$ with very valid criteria, and the graphic aspect is $95.83 \%$ with very valid criteria. Several booklet developments also obtained valid to very valid categories such as research by Rusmana et al. (2019)., Paramita et al. (2019) and some research on the development of the booklet previously described. The aspect of the content eligibility is the suitability of $\mathrm{KI}$ and $\mathrm{KI}$ in $\mathrm{C}-13$, suitability to the needs of students, suitability to the needs of learning media, the truth of material substance, benefits to increase knowledge, suitability with morality and social values, and suitability with student development. The content expert gave a score of 4 (strongly agrees) on the aspects of suitability with $\mathrm{KI}$, suitability with social norms, and suitability with the development of students, another indicator on the content eligibility is worth 3 (agree). The ESQ expert gave a score of 3 (agreed) on the benefits of the booklet to increase students' ESQ scores, another indicator on the content eligibility of ESQ in the booklet was worth 4 (strongly agree). The biology teacher gave a score of 3 (agree) on the suitability of the booklet with the development of students, another indicator on the content eligibility is 4 (strongly agree). In total, the content eligibility aspect is very valid, with a score of $92.05 \%$.

Linguistic aspects include legibility, clarity of information, conformity with Indonesian language principles, effective and efficient use of language, and the correctness of theoretical references. The content expert gave a score of 4 (strongly agrees) on the readability indicator, the suitability of the language rules used, the theoretical reference rules, other indicators have a score of 3 (agree). The ESQ expert gave a score of 3 (agree) on the indicator of information clarity, the other indicators are worth 4 (strongly agree). The biology teacher gave a score of 3 (agree) on the aspect of using 
sentences effectively and efficiently, the other indicator is worth 4 (strongly agrees). In total, the linguistic aspect obtained a very valid value, with a score $92.16 \%$.

Presentation aspects include clarity of objectives, order of presentation, provision of motivation, interactivity, and completeness of the information. The content expert and biology teacher gave a score of 3 (agree) on the presentation of the booklet interactivity, other indicators have a value of 4 (strongly agree). The ESQ expert gave a score of 3 (agree) on the clarity of the objectives and completeness of the ESQ information in the booklet, the other indicators are worth 4 (strongly agree). Overall, the linguistic aspect obtained a very valid value, with a score of $93.33 \%$.

Graphic aspects include the use of letters, color selection, layout, image selection, and display design in the booklet. Media experts gave a score of 3 (agree) on the indicator of ease of understanding the layout of the booklet, attractive cover design, attractive mind map display, and interesting bio info display, other indicators score 4 (strongly agree). The biology teacher gave a score of 3 (agree) on the suitability of the letters in the booklet, the other indicators are worth 4 (strongly agree). The ESQ expert gave a score of 4 (strongly agreed) on all indicators on the graphic aspect. Overall, the graphic aspect obtained a very valid value, with a score of $95.83 \%$. All aspects of evaluating the validity of the ESQ nuanced booklet on the material of structure and function of animal tissue are very valid, so the booklet developed is categorized as a very valid development product. According to (Sari \& Iza, 2018) with the validation test, the product is deemed appropriate to be used to expand knowledge, provide learning experiences, and products are developed according to student needs.

\section{CONCLUSION}

Based on the research that has been done, it is concluded that the average validation of the ESQ booklet about the structure and function of animal tissue with a percentage of $93.34 \%$ is categorized as very valid. The average validity score of content eligibility aspects $92.05 \%$, linguistic aspects $92.16 \%$, presentation aspects $93.33 \%$, and graphic aspects $95.83 \%$ with the percentage is very valid. The validity of the product is obtained after going through the revision stage from the advice of content experts, media experts, ESQ experts, and biology teachers to produce a final product with a very valid category. The ESQ nuanced booklet is expected to increase learning motivation, be interesting to read, increase student's ESQ scores, help Islamic religion teachers improve students' ESQ scores, and assist teachers in explaining material about the structure and function of animal tissue.

\section{ACKNOWLEDMENT}

Thank you to the students of class XI IPA 1 and XII IPA 1 as research and observation subjects, Biology teachers and stockholders of SMAN 1 Pulau Punjung, all product validators, examiners, supervisors, and the staff of Biology Department, FMIPA, Universitas Negeri Padang.

\section{REFERENCES}

Arifuddin, M., \& Bahri, A. (2019). Analisis kebutuhan pengembangan aplikasi m-learning berbasis android pada materi jaringan hewan. Biology Teaching and Learning, 2(1), 3449. Retrieved from https://ojs.unm.ac.id/bt//article/view/10812

Arikunto, S. (2010). Evaluasi program pendidikan. Bumi Aksara.

Atiko. (2019). Booklet, brosur, dan poster sebagai karya inovatif di kelas. Caremedia Communication. Fakhrurrazi, F. (2018). Hakikat pembelajaran yang efektif. Jurnal At-TafkirAt-Tafkir, 11(1), 85. https:// 
doi.org/10.32505/at.v11i1.529

Fauziyati, A. (2019). Pengaruh kecerdasan Emosional Spiritual (ESQ) terhadap kemampuan literasi digital mahasiswa PAI di fakultas tarbiyah dan keguruan. UIN Sunan Ampel Surabaya UIN Sunan Ampel. Retrieved from http://digilib.uinsby.ac.id/33044/

Fitri, E. A. (2020). Pengembangan booklet pembelahan sel sebagai suplemen bahan ajar biologi kelas XII SMA/MA. Universitas Negeri Padang. Retrieved from http://repository.unp.ac.id/30245/

Fitriasih, R., Ansori, I., \& Kasrina. (2019). Pengembangan booklet keanekaragaman pteridophyta di kawasan Suban air panas untuk siswa SMA. Diklabio: Jurnal Pendidikan Dan Pembelajaran Biologi, 3(1), 100-108. https://doi.org/10.33369/diklabio.3.1.100-108

Fransisca, M. (2017). Pengujian validitas, praktikalitas, dan efektivitas media e-learning di Sekolah Menengah Kejuruan. VOLT: Jurnal IImiah Pendidikan Teknik Elektro, 2(1), 17. http://dx.doi.org/10.30870/volt.v2i1.1091

Gilissen, M. G. R., Knippels, M. C. P. J., Verhoeff, R. P., \& van Joolingen, W. R. (2020). Teachers' and educators' perspectives on systems thinking and its implementation in dutch biology education. Journal of Biological Education, 54(5), 485-496. https://doi.org/10.1080/00219266.2019. 1609564

Harahap, I. A., Helendra, H., Farma, S. A., \& Syamsurizal, S. (2020). Validity of the human respiratory system booklets as learning suplement for student class VIII Junior High School. Bioeducation Journal, 4(2). Retrieved from http://bioeducation.ppj.unp.ac.id/index.php/bioedu/article/view/272

Hasim, R. (2020). Pengembangan lembar kegiatan siswa berbasis paikem gembrot pada materi jaringan hewan untuk meningkatkan hasil belajar siswa di kelas XI IIS Madrasah Aliyah Nurul Ikhlas Ambon. Institut Agama Islam Negeri Ambon. Retrieved from http://repository.iainambon. ac.id/435/

Herwati. (2016). Emotional Spiritual Qoutient (ESQ) dan relevansinya terhadap pendidikan agama islam. Universitas Negeri Maulana Malik Ibrahim Malang. Retrieved from http://etheses.uinmalang.ac.id/4088/

Indasari, H. (2016). Pengembangan bio-booklet filum echinodermata sebagai sumber belajar mandiri siswa kelas X SMA/MA. UIN Sunan Kalijaga. Retrieved from http://digilib.uinsuka.ac.id/id/eprint/22381

Ismail, I. (2020). Teknologi pembelajaran sebagai media pembelajaran. Cendikia Publisher.

Kinanti, A. A. (2015). Pengembangan multimedia interaktif jaringan hewan sebagai suplemen pembelajaran biologi di SMA. Universitas Negeri Semarang. Retrieved from http://lib.unnes.ac.id/23420/

Kotimah, K., \& Ambarwati, R. (2020). Development of the integrated worksheet based on a field trip aves's material topic at Surabaya Zoo to increase learning interest for 10th grade High School Students. Journal of Biology Education, 9(3), 294-305. https://doi.org/10.15294/jbe.v9i3.40144

Maemunawati, S., \& Alif, M. (2020). Peran guru, orang tua, metode dan media pembelajaran: strategi $\mathrm{kbm}$ di masa pandemi COVID-19. Penerbit 3M Media Karya Serang. Retrieved from http://repository.uinbanten.ac.id/6294/

Mirza, G. A., Ristiono, \& Handayani, D. (2018). Pengembangan lembar kegiatan peserta didik bernuansa emotional spritual quotient tentang materi sel, jaringan, organ, dan organisme untuk peserta didik kelas VII SMP/MTs. Bioeducation Journal, 3(1), 27-36. https://doi.org/10. 24036/bioedu.v3i1.108

Natsir, M. (2016). Pengembangan modul berbasis inquiri pada materi jaringan hewan kelas XI madrasah aliyah (MA) Syekh Yusuf Kec. Sombaopu Kab. Gowa. UIN Alauddin Makassar. Retrieved from http://repositori.uin-alauddin.ac.id/3423/

Nurhidayah, \& Haryunita. (2020). Pengembangan katalog jaringan hewan sebagai media pembelajaran materi jaringan hewan di SMA. Indonesian Journal of Educational Science (IJES), 02(02), 99-107. Retrieved from https://ojs.unsulbar.ac.id/index.php/ijes/article/view/692

Nurseto, T. (2011). Membuat media pembelajaran yang menarik. Jurnal Ekonomi \& Pendidikan, 8(1), 
19-35. https://doi.org/10.21831/jep.v8i1.706

Paramita, R., Panjaitan, R. G. P., \& Ariyati, E. (2019). Pengembangan booklet hasil inventarisasi tumbuhan obat sebagai media pembelajaran pada materi manfaat keanekaragaman hayati. Jurnal IPA \& Pembelajaran IPA, 2(2), 83-88. https://doi.org/10.24815/jipi.v2i2.12389

Permendikbud No 35. (2018). Perubahan atas Permendikbud No. 58 Th. 2014 tentang kurikulum 2013. Permendikbud. Retrieved from https://goeroendeso.files.wordpress.com/2019/0 1/permendikbud-no.-35-tahun-2018-kurikulum-2013-smp-mts.pdf

Permendikbud No 37. (2018). KI dan KD kurikulum 2013. Permendikbud. Retrieved from https://drive.google.com/file/d/1jfrh_X_RZuX4Ga7kYFHfRyu2EhlUk-pJ/view

Pralisaputri, K. R., Soegiyanto, H., \& Muryani, C. (2016). Pengembangan media booklet berbasis SETS pada materi pokok mitigasi dan adaptasi bencana alam untuk kelas X SMA. Jurnal GeoEco, 2(2), 147-154. Retrieved from https://jurnal.uns.ac.id/GeoEco/article/view/8930

Purnomo, A. W., \& Rahayuningsih, M. (2020). Development of dragonfly species diversity booklet in Tinjomoyo Tourism Forest as a supplement material on biodiversity topic. Journal of Biology Education, 9(3), 269-274. Retrieved from http://lib.unnes.ac.id/id/eprint/38441

Purwanto. (2018). Teknik penyusunan instrumen. Staia Press.

Puspita, A., Kurniawan, A. D., \& Rahayu, H. M. (2017). Pengembangan media pembelajaran booklet pada materi sistem imun terhadap hasil belajar sswa kelas XI SMAN 8 Pontianak. Jurnal Bioeducation, 4(1), 64-73. http://dx.doi.org/10.29406/524

Putra, R., Armen, \& Handayani, D. (2017). Pengembangan modul pembelajaran biologi bernuansa Emotional Spiritual Quotient (ESQ) pada materi sistem peredaran darah untuk siswa kelas VIII SMP/MTs. Journal Biosains, 1(2), 269-276. Retrieved from http://ejournal.unp.ac.id/students/ index.php/bio/issue/download/355/58

Rahmadhani, F., Armen, Darussyamsu, R., Fadilah, M., \& Putri, D. H. (2019). The development of biology module based on emotional spiritual quotient in evolution topic for Senior High School. Scientiae Educatia: Jurnal Pendidikan SAINS, 8(2), 166179. https://doi.org/http://dx.doi.org/10. 24235/sc.educatia.v8i2.2525

Rehusisma, L. A., Indriwati, S. E., \& Suarsini, E. (2017). Pengembangan media pembelajaran booklet dan video sebagai penguatan karakter hidup bersih dan sehat. Jurnal Pendidikan: Teori, Penelitian, Dan Pengembangan, 2(9), 1238-1243. http://dx.doi.org/10.17977/jptpp.v2i9.9964

Riyana, C. (2012). Media pembelajaran. Bandung. CV Wacana Prima.

Rusmana, J., Ramdiah, S., \& Prayitno, B. (2019). Pengembangan booklet sebagai sumber belajar biologi melalui nilai-nilai kearifan lokal dalam pembuatan bakul purun. Prosiding Seminar Nasional Lingkungan Lahan Basah, 4(April), 603-607. Retrieved from https://snllb.ulm.ac.id/ prosiding/index.php/snllb-lit/article/view/254

Samhuliya, D. (2019). Pola-pola hereditas pada makhluk hidup sebagai suplemen bahan ajar genetika di SMA. Universitas Negeri Padang. Retrieved from http://repository.unp.ac.id/id/eprint/24794

Sari, N. K., \& Iza, N. (2018). Pengembangan handout evolusi berbasis hasil penelitian profil DNA fingerprinting. Edubiotik : Jurnal Pendidikan, Biologi dan Terapan, 3(02), 37-47. https://doi.org/ 10.33503/ebio.v3i02.252

Sepriadi, I., Sumarmin, R., \& Fitri, R. (2018). Pengembangan media animal comic (anicom) berorientasi pendekatan kontekstual untuk peserta didik kelas X. Bioeducation Journal, 2(2), 178-188. https://doi.org/10.24036/bioedu.v2i2.103

Warliah, W., Listianti, F., Hasanah, T. I., \& Maimuna, U. (2018). Pengembangan media pembelajaran berbasis widya wisata. Pamengkasan. Duta Media Publishing.

Yulmi. (2018). Pengembangan buku saku bergambar sebagai media belajar mandiri pada materi struktur dan fungsi jaringan pada tumbuhan dan hewan. Universitas Islam Negeri Raden Intan Lampung. Retrieved from http://repository.radenintan.ac.id/5669/ 